\title{
Relationship between retinopathy and renal abnormalities in black hypertensive patients
}

\author{
A. B. Omotoso', P. M. Kolo ${ }^{1 *}$, T. O. Olanrewaju', J. F. Owoeye², S. A. Biliaminu ${ }^{3}$ and V. A. Olatunji ${ }^{4}$
}

\begin{abstract}
Background: Complications of hypertension are particularly common in people of African descent but previous reports had suggested rarity of hypertensive retinopathy in black Africans. We evaluated retinal changes among Nigerian hypertensive patients and determined their relationship with renal function.

Methods: Consecutive Hypertensive patients who were $\geq 18$ years were selected for the study. Socio-demographic characteristics, anthropometric parameters and blood pressure were measured. All patients had ophthalmoscopic examination and retinal changes were graded according to Keith-Wegener's classification. Blood samples were taken for blood urea nitrogen, lipids and C-reactive protein; and urine was collected for creatinine and microalbuminuria. Serum creatinine was determined using modified Jaffe method and estimated glomerular filtration (eGFR) was calculated using MDRD equation: $186 \times(\text { Creatinine/88.4 })^{-1.154} \times(\text { Age })^{-0.203} \times(0.742$ if female $) \times(1.210$ if black $)$.

Results: Of the 240 patients studied, 187 (78 \%) had one form of retinopathy or the other. While 85 (35.4\%) patients had grade 1 retinopathy, 87 (36.3 \%) had grade 2, 13 (5.4\%) had grade 3 and $2(0.83 \%)$ had grade 4 respectively. Comparison of patients with and without retinopathy showed that, the former were older $(p=0.001)$ and had longer duration of hypertension $(p=0.001)$. Similarly, hypertensive patients with retinopathy had higher total cholesterol and low density lipoprotein cholesterol ( $p=0.017, p=0.041$ respectively). However, eGFR was lower in individuals with retinopathy $(46.2 \mathrm{ml} / \mathrm{min} / 1.73)$ than those with normal retinal $(55.9 \mathrm{ml} / \mathrm{min} / 1.73)$ findings, $p=0.019$. Multi-variable adjusted odds ratios showed increased probability of retinopathy with age (odds ratio-1.08, $p=0.001$ ) and body mass index (odds ratio-1.20, $p=0.013$ ).
\end{abstract}

Conclusions: Hypertensive retinopathy is a common clinical finding among hypertensive Nigerians and may occur pari passu with renal damage as consequences of long standing hypertension.

Keywords: Hypertension, Complications, Retinopathy, Kidney disease, Black Africans

\section{Background}

Systemic hypertension is a major public health concern that affects more than one billion people world-wide [1]. The prevalence of hypertension is known to be high in black Africans in whom the disease presents early and runs a rapid course [2]. Retinal micro-vascular abnormalities such as arterial narrowing, arteriovenous nicking and retinopathy reflect the vascular damage from hypertension [3]. These retinal changes appear to be irreversible long term markers of hypertension and may

\footnotetext{
* Correspondence: etsumanma@yahoo.com

'Department of Medicine, University of llorin, P.M.B. 1515, llorin, Nigeria

Full list of author information is available at the end of the article
}

relate to current and past blood pressures. The presence of retinopathy indicates that a person's hypertension has progressed to a severe stage with associated target organ damage [4]. Blood vessel damage in the eye as a result of hypertension has been tracked with similar changes in the brain and has been found to be a potential risk of stroke and death, independent of known risk factors [5]. The presence of retinopathy may be an indication for initiating antihypertensive treatment, even in people with stage 1 hypertension (blood pressure, 140 to 159/90 to $99 \mathrm{~mm} \mathrm{Hg}$ ) who have no other evidence of targetorgan damage [6]. Although, an earlier study among continental Africans [7] showed hypertensive retinopathy 
to be rare, evidence is accumulating to suggest that the incidence of hypertensive retinopathy is higher among Africans than Caucasians in United States of America [8, 9]. Blacks are also more likely to develop hypertension-related complications such as heart failure, stroke and kidney diseases than Whites. Indeed, the combination of target organ damage (left ventricular hypertrophy (LVH) and chronic kidney disease) in patients with systemic hypertension has been found to exaggerate risk of cardiovascular events [10]. The involvement of retina in hypertension is similar to the blood vessel damage in the kidneys (arteriosclerosis) but whether this occur simultaneously in the course of the disease is not very clear. We therefore evaluated retinal and renal profiles in hypertensive patients in our hospital.

\section{Methods}

The study was a descriptive cross sectional evaluation of retinal morphology and renal function among hypertensive patients that were managed at the Medical OutPatient Department (MOPD) of our hospital. Consecutive hypertensive patients seen at the MOPD were recruited if they were $\geq 18$ years and gave informed consent. Hypertensive patients, who were diabetic, had sickle cell anaemia, had history of glaucoma, pregnant and those with secondary hypertension were excluded from the study. Ethical approval was obtained from the Ethics and Research Committee of the University of Ilorin Teaching hospital, Nigeria. The socio-demographic characteristics of the participants were obtained and a thorough history including the duration of hypertension, drug therapy and compliance was taken. The anthropometric parameters, blood pressure and other relevant clinical examination were performed on the patients. Blood pressure was measured at the left arm in a comfortable sitting position after about 10 min rest using standard mercury sphygmomanometer (Accoson) with an appropriate cuff. However, if the blood pressure was equal or greater than $10 \mathrm{mmHg}$ at the right arm, the latter blood pressure was used as the blood pressure of the subjects. An average of three measurements was taken as the patient's blood pressure. Hypertension was defined according to the JNC VII (BP $\geq$ 140/90 $\mathrm{mmHg}$ or anti-hypertensive use) [11]. The intraocular pressure was measured using Perkins applanation tonometer. All patients had ophthalmoscopic examination done by one of the ophthalmologists (OVA) on the team after pupillary dilatation with $0.5 \%$ cyclopentolate eye drops or $1 \%$ tropicamide and retinal changes compatible with hypertensive changes were assessed. The severity of patient's retinal changes was determined and graded according to Keith-Wegener's classification. When in doubt the opinion of the second ophthalmologist (JFO, more experienced) was sort who also intermittent examine sample of patients for concordance. Blood samples were taken from each patient for blood urea nitrogen, lipids and Creactive protein; and urine was collected for creatinine and microalbuminuria. Serum Blood urea nitrogen was determined using Modified Berthelot's method. Serum C-reactive protein was determined using Turbilatex method with high sensitivity and specificity. Serum estimation of high density lipoprotein cholesterol (HDL-c) and low density lipoprotein cholesterol (LDL-c) were done using Direct Immunoinhibition method. Serum Total Cholesterol and Triglycerides were determined using colorimetric enzymatic method. Urine Microalbumin was determined using quantitative Turbidimetric Immunoassay method. Albumin creatinine ratio (ACR) was calculated using the formula: Urine Albumin $(\mathrm{mg} / \mathrm{dL}) /$ Urine Creatinine $(\mathrm{g} / \mathrm{dL})=\mathrm{ACR}$ in $\mathrm{mg} / \mathrm{g} \approx$ Albumin excretion in $\mathrm{mg} /$ day. Serum Creatinine was determined using modified Jaffe method and eGFR was calculated using MDRD equation: $186 \times(\text { Creat } / 88.4)^{-1.154} \times(\text { Age })^{-0.203} \times(0.742$ if female $) \times(1.210$ if black $)$. Where unit of eGFR $=\mathrm{mL} / \mathrm{min} /$ $1.73 \mathrm{~m}^{2}$, serum creatinine $=\mu \mathrm{mol} / \mathrm{L}$ and age $=$ years. Serum Uric Acid was determined using Uricase-PAP method. All the kits used were manufactured by Agappe Diagnostics International and supplied by NUMS Diagnostics Nigeria Ltd. Suleja.

\section{Data analysis}

Statistical analysis was performed using the SPSS Version 15 (SPSS Inc, Chicago Illinois, USA 2006 edition) and the numerical values were presented as mean $\pm S D$. Student $t$ test was used to compare means of continuous variables while chi-square test was used to compare means of proportions. Means of variables of interest in patients with and without retinopathy; and those with ACR $\leq 300 \mathrm{mg} / \mathrm{g}$ and $>300 \mathrm{mg} / \mathrm{g}$ were compared using independent $\mathrm{t}$-test. Relationship between retinopathy and other variables of interest were determined by Spearman's Rank correlation method. Those variables that have no significant correlations with retinopathy were excluded from analysis and the strength of association of each of the remaining variables was assessed using partial correlation statistics. Binary logistic regression was used to determine predictors of retinopathy and the products were expressed as odd ratio with $95 \%$ confident interval. A statistically significant association was set at $P<0.05$.

\section{Results}

Two hundred and forty hypertensive patients comprising of $160(66.7 \%)$ women and $80(33.3 \%)$ men were studied with mean age of $58.9 \pm 12.1$ years. Baseline clinical and biochemical characteristics of the patients are shown in Table 1 . The mean BMI in the study participants was $26.6 \pm 5.8 \mathrm{~kg} / \mathrm{m}^{2}$ which is in the over-weight category. The mean total cholesterol was $5.9 \pm 1.5 \mathrm{mmol} / \mathrm{l}$ ) while the mean of HDL-c was $0.9 \pm 0.2 \mathrm{mmol} / \mathrm{l}$ with coronary artery 
Table 1 Baseline characteristics of the patients $(n=240)$. Characteristics are presented as mean $\pm \mathrm{SD}$, median (range)

\begin{tabular}{ll}
\hline Gender (Male/Female), $\mathrm{n}(\%)$ & $80 / 160(33.3 / 66.7)$ \\
\hline Age (years) & $58.9 \pm 12.1$ \\
Duration of hypertension (years) & $6(1-37)$ \\
Body Mass Index $\left(\mathrm{Kg} / \mathrm{m}^{2}\right)$ & $26.6(5.8)$ \\
Systolic Blood pressure $(\mathrm{mmHg})$ & $139.86 \pm 22.1$ \\
Mean Arterial Pressure $(\mathrm{mmHg})$ & $104.1 \pm 15.0$ \\
Pulse Pressure (mmHg) & $53.3 \pm 16.5$ \\
Diastolic Blood Pressure $(\mathrm{mmHg})$ & $86.3 \pm 13.6$ \\
Mean Blood Pressure(mmHg) & $97.4 \pm 7.9$ \\
Waist Circumference $(\mathrm{m})$ & $97.4 \pm 14.4$ \\
Hip Circumference $(\mathrm{m})$ & $101.7 \pm 14.1$ \\
Waist Hip Ratio & $0.97 \pm 0.11$ \\
Uric Acid (mmol/L) & $7.5 \pm 3.4$ \\
Total cholesterol $(\mathrm{mmol} / \mathrm{L})$ & $5.9 \pm 1.5$ \\
HDL-Cholesterol $(\mathrm{mmol} / \mathrm{L})$ & $0.9(0.2)$ \\
Triglyceride $(\mathrm{mmol} / \mathrm{L})$ & $2.2(0.9)$ \\
Low Density Lipoprotein $(\mathrm{mmol} / \mathrm{L})$ & $2.8 \pm 1.0$ \\
C-Reactive Protein $(\mathrm{g} / \mathrm{L})$ & $7.8 \pm 2.8$ \\
Albumin-Creatinine Ratio (mg/g) & $93.9(3.3-1931.3)$ \\
eGFR by MDRD (ml/min/1.73) & $49.3(16.5-167.2)$ \\
\hline
\end{tabular}

disease risk ratio of 6.6 . Median of the eGFR was 49.3 (range 16.5-167.2) $\mathrm{mL} / \mathrm{min} / 1.73 \mathrm{~m}^{2}$ which suggests that significant number of the patients had reduced kidney function. Similarly, the median of ACR was 93.9 (3.3$1931.3 \mathrm{mg} / \mathrm{g}$ ) which also suggests that a good number of subjects had significant albuminuria.

Figure 1 shows frequency of hypertensive retinopathies among the participants. One hundred and eighty seven

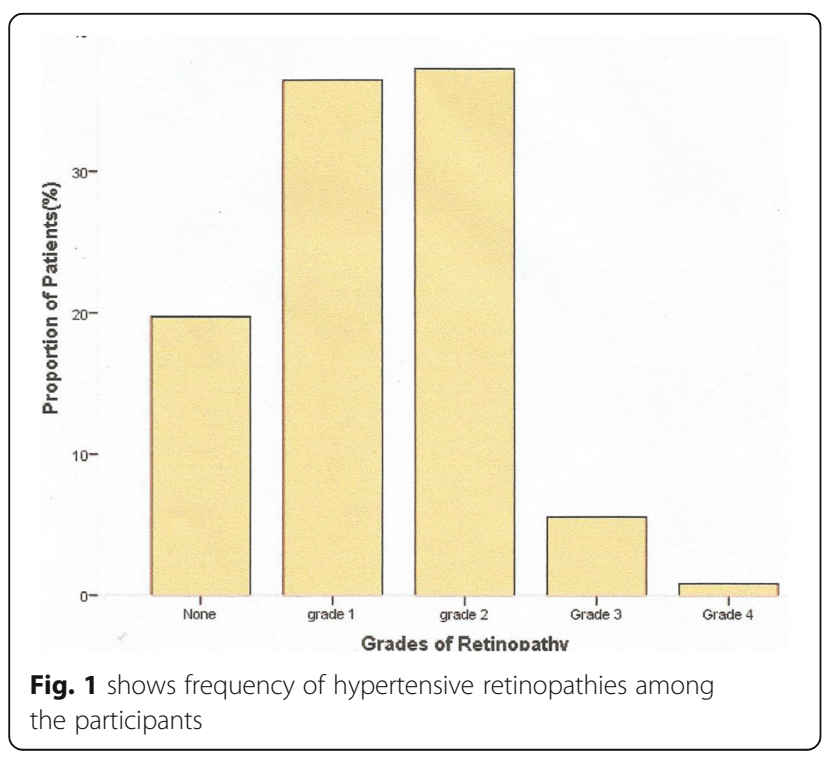

patients $(78 \%)$ had one form of retinopathy or the other. While $85(35.4 \%)$ patients had grade 1 retinopathy, 87 (36.3\%) had grade 2, $13(5.4 \%)$ had grade 3 and 2 $(0.83 \%)$ had grade 4 respectively.

When patients with hypertensive retinopathy were compared with those without retinopathy, the former were older $(p=0.001)$ and had longer duration of systemic hypertension $(p=0.001)$ as shown in Table 2 . Similarly, hypertensive patients with retinopathy have higher total cholesterol and low density lipoprotein cholesterol ( $p=0.017, p=0.041$ respectively). On the other hand, eGFR was lower in individuals with hypertensive retinopathy $(46.2 \mathrm{ml} / \mathrm{min} / 1.73)$ compared with those with normal retinal $(55.9 \mathrm{ml} / \mathrm{min} / 1.73)$ findings, $p=0.019$. However, body mass index, blood pressure indices, Creactive protein and ACR were similar between patients with and without retinopathy. Similarly, patients on drug combinations that included angiotensin converting enzyme inhibitors (ACEI) were compared with those on combinations without ACEI. All parameters compared were similar except ACR which was lower in those on ACEI than those not on ACEI. The median of ACR was $77.3(5.78-1931.3 \mathrm{mg} / \mathrm{g})$ in the former and $104.6(3.34-$ $1706.3 \mathrm{mg} / \mathrm{g})$ in the latter. In addition, fewer patients on ACEI (40.4\%) have grades II-IV retinopathy compared with those not on ACEI (46.4\%), $p=0.346$.

Comparison of patients with ACR $\leq 300 \mathrm{mg} / \mathrm{g}$ against those who had ACR $>300 \mathrm{mg} / \mathrm{g}$ is presented in Table 3 . The mean age and duration of hypertension were similar between the former and the latter. Patients with ACR > $300 \mathrm{mg} / \mathrm{g}$ have higher percentage of grade II-IV retinopathy, serum uric acid level, total cholesterol, low density lipoprotein cholesterol, triglycerides and C-reactive protein than those with $\mathrm{ACR} \leq 300 \mathrm{mg} / \mathrm{g}$. On the other hand, those with ACR $>300 \mathrm{mg} / \mathrm{g}$ have lower high density lipoprotein cholesterol and eGFR.

Correlates of hypertensive retinopathy are shown in Table 4. Significant positive correlations were observed between age, duration of hypertension, body mass index, total cholesterol, LDL-c and C-reactive protein with retinopathy. On the other hand, significant negative correlation was observed between eGFR and retinopathy. However, when each of the parameters were assessed individually (partial correlation), the correlation of total cholesterol and C-reactive protein with retinopathy were no longer significant. Binary logistic regression to determine predictors of retinopathy is presented in Table 5. Multi-variable adjusted odds ratios showed increased probability of retinopathy with age (odds ratio-1.08, $p=0.001$ ) and body mass index (odds ratio- $1.20, p=0.013$ )

\section{Discussion}

Systemic hypertension remains the most prevalent cardiovascular risk factor in indigenous African population 
Table 2 Characteristics of patients with and without retinopathy. Characteristics are presented as mean $\pm S D$, median (range)

\begin{tabular}{|c|c|c|c|}
\hline & Patients with retinopathy $(n=187)$ & Patients without retinopathy $(n=46)$ & $P$ value \\
\hline Gender (Male/Female), n(\%) & $80 / 160(33.3 / 66.7)$ & & \\
\hline Age (years) & $61.7 \pm 10.5$ & $47.2 \pm 12.0$ & 0.001 \\
\hline Duration of hypertension (years) & $7(1-37)$ & $4.5(1-15)$ & 0.001 \\
\hline Body Mass Index $\left(\mathrm{Kg} / \mathrm{m}^{2}\right)$ & $26.9 \pm 6.0$ & $26.1 \pm 4.9$ & 0.422 \\
\hline Systolic Blood pressure (mmHg) & $139.5 \pm 22.6$ & $141.2 \pm 20.8$ & 0.657 \\
\hline Diastolic Blood Pressure $(\mathrm{mmHg})$ & $85.8 \pm 14.0$ & $88.8 \pm 11.8$ & 0.183 \\
\hline Mean Blood Pressure(mmHg) & $103.7 \pm 15.4$ & $106.2 \pm 13.9$ & 0.307 \\
\hline Pulse Pressure $(\mathrm{mmHg})$ & $53.8 \pm 17.2$ & $52.4 \pm 14.2$ & 0.307 \\
\hline Waist Circumference (m) & $98.0 \pm 14.7$ & $95.6 \pm 13.8$ & 0.321 \\
\hline Hip Circumference (m) & $102.3 \pm 13.9$ & $99.9 \pm 14.8$ & 0.308 \\
\hline Waist Hip Ratio & $0.97 \pm 0.11$ & $0.96 \pm 0.13$ & 0.751 \\
\hline Uric Acid (mmol/L) & $7.5 \pm 3.4$ & $7.5 \pm 3.4$ & 0.966 \\
\hline Total cholesterol (mmol/L) & $6.1 \pm 1.4$ & $5.4 \pm 1.7$ & 0.017 \\
\hline HDL-Cholesterol (mmol/L) & $0.93 \pm 0.21$ & $0.91 \pm 0.21$ & 0.593 \\
\hline Triglyceride (mmol/L) & $2.3 \pm(1.0)$ & $2.0 \pm 0.8$ & 0.130 \\
\hline Low Density Lipoprotein (mmol/L) & $2.9 \pm 1.0$ & $2.5 \pm 1.2$ & 0.041 \\
\hline C-Reactive Protein (g/L) & $7.9 \pm 2.8$ & $7.2 \pm 3.1$ & 0.116 \\
\hline Albumin-Creatinine Ratio (mg/g) & 93.9(3.9-1931.3) & 109.6(3.3-1580) & 0.908 \\
\hline eGFR by MDRD (ml/min/1.73) & $46.2(16.5-167.2)$ & $55.9(22.5-165.4)$ & 0.019 \\
\hline
\end{tabular}

Table 3 Characteristics of patients with ACR equal or less than 300 mg/g and greater than $300 \mathrm{mg} / \mathrm{g}$ Characteristics are presented as mean $\pm \mathrm{SD}$, median (range) or number (\%)

\begin{tabular}{|c|c|c|c|}
\hline & Patients with ACR $\leq 300 \mathrm{mg} / \mathrm{g}(n=167)$ & Patients with ACR > $300 \mathrm{mg} / \mathrm{g}(n=62)$ & $P$ value \\
\hline Gender (Male/Female), n(\%) & $80 / 160(33.3 / 66.7)$ & & \\
\hline Age (years) & $58.6 \pm 11.4$ & $57.5 \pm 12.8$ & 0.548 \\
\hline Duration of hypertension (years) & $7.8 \pm 7.1$ & $7.8 \pm 6.6$ & 0.979 \\
\hline Body Mass Index $\left(\mathrm{Kg} / \mathrm{m}^{2}\right)$ & $26.2 \pm 5.3$ & $27.9 \pm 6.8$ & 0.060 \\
\hline Systolic Blood pressure (mmHg) & $139.6 \pm 20.8$ & $137.2 \pm 20.1$ & 0.470 \\
\hline Diastolic Blood Pressure (mmHg) & $86.1 \pm 13.2$ & $86.3 \pm 12.5$ & 0.895 \\
\hline Mean Blood Pressure $(\mathrm{mmHg})$ & $103.9 \pm 14.1$ & $103.3 \pm 13.7$ & 0.783 \\
\hline Pulse Pressure $(\mathrm{mmHg})$ & $53.6 \pm 16.6$ & $50.9 \pm 15.2$ & 0.309 \\
\hline Waist Circumference (m) & $96.9 \pm 12.0$ & $98.1 \pm 19.5$ & 0.579 \\
\hline Hip Circumference (m) & $101.5 \pm 12.9$ & $103.4 \pm 14.4$ & 0.380 \\
\hline Waist Hip Ratio & $0.96 \pm 0.11$ & $0.96 \pm 0.08$ & 0.882 \\
\hline Uric Acid (mmol/L) & $7.2 \pm 3.0$ & $8.6 \pm 4.4$ & 0.017 \\
\hline Total cholesterol (mmol/L) & $5.7 \pm 1.5$ & $6.9 \pm 1.1$ & 0.001 \\
\hline HDL-Cholesterol (mmol/L) & $0.95 \pm 0.23$ & $0.89 \pm 0.13$ & 0.040 \\
\hline Triglyceride (mmol/L) & $2.1 \pm(1.0)$ & $2.7 \pm 0.9$ & 0.001 \\
\hline Low Density Lipoprotein (mmol/L) & $2.7 \pm 1.0$ & $3.4 \pm 0.8$ & 0.001 \\
\hline C-Reactive Protein (g/L) & $7.5 \pm 2.7$ & $9.2 \pm 2.2$ & 0.001 \\
\hline Retinopathy (II-IV) Frequency\% & $34(58.6 \%)$ & $63(42.3 \%)$ & 0.0316 \\
\hline eGFR by MDRD (ml/min/1.73) & $58.8 \pm 28.9$ & $50.3 \pm 19.2$ & 0.021 \\
\hline
\end{tabular}


Table 4 Association of retinopathy with clinical and laboratory characteristics

\begin{tabular}{lcc}
\hline Characteristic & Correlation coefficient & $P$ value \\
\hline Age (years) & 0.41 & 0.001 \\
Duration of hypertension (years) & 0.29 & 0.001 \\
Body Mass Index $\left(\mathrm{Kg} / \mathrm{m}^{2}\right)$ & 0.16 & 0.017 \\
Systolic Blood pressure $(\mathrm{mmHg})$ & 0.07 & 0.295 \\
Diastolic Blood Pressure $(\mathrm{mmHg})$ & -0.05 & 0.946 \\
Mean Blood Pressure $(\mathrm{mm} H \mathrm{Hg})$ & -0.03 & 0.637 \\
Pulse Pressure $(\mathrm{mmHg})$ & 0.10 & 0.145 \\
Waist Circumference $(\mathrm{m})$ & 0.09 & 0.200 \\
Hip Circumference $(\mathrm{m})$ & 0.04 & 0.574 \\
Waist Hip Ratio & 0.08 & 0.226 \\
Uric Acid (mmol/L) & -0.001 & 0.990 \\
Total cholesterol $(\mathrm{mmol} / \mathrm{L})$ & 0.22 & 0.002 \\
HDL-Cholesterol $(\mathrm{mmol} / \mathrm{L})$ & -0.01 & 0.885 \\
Low Density Lipoprotein $(\mathrm{mmol} / \mathrm{L})$ & 0.23 & 0.001 \\
Triglyceride $(\mathrm{mmol} / \mathrm{L})$ & 0.11 & 0.111 \\
Albumin-Creatinine Ratio $(\mathrm{mg} / \mathrm{g})$ & 0.002 & 0.974 \\
C-Reactive Protein $(\mathrm{g} / \mathrm{L})$ & 0.17 & 0.016 \\
eGFR by MDRD $(\mathrm{ml} / \mathrm{min} / 1.73)$ & -0.26 & 0.001 \\
\hline
\end{tabular}

and a major cause of cardiovascular events. This prospective cross sectional study evaluated common complications of the eye and the kidneys among hypertensive individuals. The prevalence of hypertensive retinopathy among the study participants was $78 \%$. This prevalence is comparable with that of Ladipo [8] who reported a prevalence of over $70 \%$ among Nigeria hypertensive patients. Our result is also similar to prevalence of retinopathy reported among black hypertensive patients in other African countries $[9,12,13]$, but higher than results among hypertensive patients in Europe [14] and blacks in United States of America [15]. On the other hand, our finding contrasts that of Akinkugbe [7] who reported that hypertensive retinopathy was a rare occurrence among African patients.

Table 5 Multi-variable adjusted odds ratio for probability of retinopathy

\begin{tabular}{llll}
\hline Variables & Odd Ratio & $95 \% \mathrm{Cl}$ & $P$-value \\
\hline Age & 1.08 & $1.044-1.127$ & $0.001^{*}$ \\
DOH & 1.05 & $0.996-1.115$ & 0.067 \\
BMI & 1.20 & $1.040-1.389$ & $0.013^{*}$ \\
SBP & 1.01 & $0.987-1.031$ & 0.448 \\
DBP & 1.02 & $0.984-1.055$ & 0.300 \\
ACR & 1.00 & $1.000-1.002$ & 0.211 \\
eGFR & 1.00 & $0.969-1.005$ & 0.146
\end{tabular}

Key: $\mathrm{Cl}$ confidence interval, $\mathrm{DOH}$ duration of hypertension, $\mathrm{BMI}$ body mass index, $S B P$ systolic blood pressure, $D B P$ diastolic blood pressure, $A C R$ albumin creatinine ratio, estimated glomerular filtration rate

*statistically significant
Perhaps, patients' selection and sample size may account for this difference as Akinkugbe's study was limited by small sample size and heterogeneous nature of his sample population. Complications of hypertension such as LVH, stroke and kidney failure have been reported to be commoner among Blacks than the Whites; and retinal changes may not be an exception as shown in our study. The high prevalence of retinopathy (an indication of changes in the cerebral arteries) among study participants may also explain why there is high prevalence of stroke in our hypertensive population [16].

Patients who had retinopathy are older than those with normal retinal examination and positive correlation was observed between age and retinopathy. Age has been demonstrated as an independent predictor of retinopathy in patients with hypertension in other studies [17, 18]. Age together with other factors such as duration of hypertension, BMI, total cholesterol, LDL-c and C-reactive protein correlated with retinal changes in our patients. The clustering of cardiovascular risk factors in the patients studied could account for high prevalence of hypertensive retinopathy.

Blood pressure indices (systolic and diastolic blood pressures) have been found to be associated with risk of development of hypertensive retinal changes $[19,20]$. This is because hypertensive retinopathy is a reflection of severity of blood pressure elevation and control over a period of time. However, systolic and diastolic blood pressures were similar between patients with retinopathy and those without in our study.

Analysis of renal function among the study participants showed that eGFR was lower $(46.2 \mathrm{ml} / \mathrm{min} / 1.73)$ in those with retinopathy than those without $(55.9 \mathrm{ml} /$ $\min / 1.73), p=0.019$. Similarly, a significant negative correlation was observed between the presence of retinopathy and eGFR $(R=-0.26, P=0.001)$. These results show that a significant number of our hypertensive patients had reduction in their renal function and this may occur simultaneous with other end organ consequence of the disease including retinal changes. In addition, ACR showed that a significant number of the patients studied had albuminuria which is an indication of glomerular dysfunction [21]. When patients with $A C R \leq 300 \mathrm{mg} / \mathrm{g}$ were compared with those with ACR $>300 \mathrm{mg} / \mathrm{g}$, the latter have higher percentage of grades II-IV retinopathy, higher levels of serum uric acid, C-reactive protein and dyslipidaemia than the former. This is an indication of a more severe disease among those with ACR $>300 \mathrm{mg} / \mathrm{g}$ than those with ACR $\leq 300 \mathrm{mg} / \mathrm{g}$. Elevated serum uric acid level is associated with increased risk of chronic kidney disease [22]. Long standing hypertension is associated with vascular changes (arteriosclerosis) which occur in all organs of the body including the eyes. Therefore, the presence of hypertensive retinopathy 
detected at fundoscopy may be an indication for a more extensive evaluation of function of other target organs in hypertension such as the kidneys [23].

Multi-variable adjusted odds ratios showed increased probability of retinopathy with age (odds ratio-1.08, $p=$ 0.001 ) and body mass index (odds ratio-1.20, $p=0.013$ ). Obesity is considered to be a major cardiovascular risk factor and microalbuminuria is an indication of renal disease. Indeed, retinopathy, LVH and microalbuminuria are considered as evidence of target organ damage in systemic hypertension. Our study further confirmed the beneficial role of ACEIs in the management of systemic hypertension [24]. It is worthy of note that patients on drug combinations including ACEIs had lower ACR compared with those not on this drug. ACEIs protect the kidneys and can prevent or delay onset of proteinuria in kidney disease.

This study was limited by over representation of women in our study participants which is a reflection of health seeking behaviours among hypertensive patients seen in our practice. Therefore, it may be difficult to generalize our result to our population. Secondly, direct ophalmoscopy was employed in the assessment of the retina in our patients. Although, this is not inferior to retinal photographs but might have provided opportunity for further reviews.

\section{Conclusion}

Hypertensive retinopathy is a common clinical finding among hypertensive Nigerians and occurs pari passu with renal damage as consequences of long standing hypertension. The presence of hypertensive retinopathy may be an indication for further assessment of affected individual especially the renal function.

\section{Abbreviations \\ ACEl: Angiotensin converting enzyme inhibitor; ACR: Albumin creatinine ratio; BMI: Body mass index; eGFR: Estimated glomerular filtration rate; HDL-c: High density lipoprotein cholesterol; JNC: Joint National Committee; LDL-c: Low density lipoprotein cholesterol; LVH: Left ventricular hypertrophy; MDRD: Modification of diet in renal disease; MOPD: Medical out-patient department}

\section{Acknowledgements}

The authors are grateful to the clinic nurses, interns and resident doctors of the Cardiology Unit who participated actively in the recruitment of the patients.

\section{Funding}

This study was funded by the Senate Research Grant (Faculty based), of University of llorin. The funder had no role in the study design, data collection and analysis, decision to publish, or preparation of the manuscript.

\section{Availability of data and materials}

Although the study is not a clinical trial or genetic study, the materials not included as part of the data are available.

\section{Authors' contributions}

Prof $A B O$ conceived the idea of the study, was involved in the study design and data interpretation. Dr PMK was involved in the design of the work, acquisition and analysis of data; drafting of the manuscript. Dr TOO was involved in study design, initial literature search, data analysis and interpretation while Professor JFO and Dr VAO were part of the design, ophthalmological data acquisition and interpretation of results. Similarly, Dr SAB was involved in the study design, laboratory analysis and data interpretation. All authors reviewed and approved the final manuscript.

\section{Competing interests}

The authors declare that they have no competing interests.

\section{Consent for publication}

Although the manuscript does not involve the use of live photograph of any of the participants, consent was obtained from them for the data to be published as at the time recruitment into the study.

\section{Ethics approval and consent to participate}

Ethical approval was obtained from the Ethics and Research Committee of our hospital. Verbal and written well informed consent was obtained from all participants before they were eligible for recruitment into the study.

\section{Author details}

${ }^{1}$ Department of Medicine, University of Ilorin, P.M.B. 1515, Ilorin, Nigeria. ${ }^{2}$ Department of Ophthalmology, University of Ilorin, P.M.B. 1515, Ilorin, Nigeria. ${ }^{3}$ Department of Chemical Pathology, University of Ilorin, P.M.B. 1515, Ilorin, Nigeria. ${ }^{4}$ Department of Ophthalmology, University of Ilorin Teaching Hospital, P.M.B. 1459, llorin, Nigeria.

Received: 15 May 2016 Accepted: 10 October 2016

Published online: 21 October 2016

\section{References}

1. Joffres M, Falascheetti E, Gillespie C, Robitaille C, Loustalot F, Poulter N, et al. Hypertension prevalence, awareness, treatment and control in national surveys from England, the USA and Canada, and correlation with stroke and ischemic heart disease mortality: a cross-sectional study. BMJ Open. 2013;3: e003423. Available at: http://bmjopen.bmj.com/content/3/8/e003423.abstract.

2. Brewster LM, Seedat YK. Why do hypertensive patients of African ancestry respond better to calcium blockers and diuretics than to ACE inhibitors and B-adrenergic blockers? A systematic review. BMC Med. 2013;11:141. Available at: http://www.ncbi.nlm.nih.gov/pmc/articles/PMC3681568/.

3. Wong TY, Klein R, Klein BEK, Tielsch JM, Mat LH, Nieto FJ. Retinal microvascular abnormalities and their relationship with hypertension, cardiovascular disease and mortality. Surv Ophthalmol. 2001;46(1):59-80. Available at: http://www.ncbi.n/m.nih.gov/pubmed/11525792.

4. Klein R, Klein BEK, Moss SE, Wang Q. Hypertension and retinopathy, arteriolar narrowing and arteriovenous nicking in a population. Arc Ophthalmol. 1994;112:92-8. Available at: http://www.ncbi.nlm.nih.gov/ pubmed/8285901.

5. Wong TY, Klein R, Couper DJ, Cooper LS, Shahar E, Hubbard LD, et al. Retinal microvascular abnormalities and incident stroke: the atherosclerosis risk in communities study. Lancet. 2001;358:1134-40. Available at: http://www.ncbi.nlm.nih.gov/pubmed/11597667.

6. The Sixth Report of the Joint National Committee on Prevention, detection, evaluation, and treatment of high blood pressure. Arch Intern Med. 1997; 157:2413-2446. [Erratum, Arch Intern Med. 1998;158:573]. Available at: http://www.ncbi.nlm.nih.gov/pubmed/9385294.

7. Akinkugbe 00 . The rarity of hypertensive retinopathy in the African. Am J Med. 1968;45:401-4. Available at: http://www.sciencedirect.com/science/ article/pii/0002934368900740.

8. Ladipo GOA. Hypertensive retinopathy in Nigerians: a prospective clinical study of 350 cases. Trop Geogr Med. 1981;33:311-6. Available at: http://www.ncbi.nlm.nih.gov/pubmed/7342375

9. Kabedi NN, Mwanza J, Lepira FB, Kayembe TK, Kayembe DL. Hypertensive retinopathy and its association with cardiovascular, renal and cerebrovascular morbidity and mortality in Congolese patients. Cardiovasc J Afr. 2014;25(5):228-32. Available at: http://www.ncbi.nlm.nih.gov/pmc/ articles/PMC4241591/.

10. Carpinella G, Pagano G, Buono F, Petitto M, Guarino G, Orefice G, et al. Prognostic value of combined target-organ damage in patients with essential hypertension. Am J Hypertens. 2015;28(1):127-34. Available at: http://www.ncbi.nlm.nih.gov/pubmed/24936579. 
11. Chobanian AV, Bakris GL, Black BK, Cushman WC, Green LA, Izzo JL, et al. The National High Blood Pressure Education Program Coordinating Committee. Seventh report of the Joint National Committee on prevention, detection, evaluation, and treatment of high blood pressure. Hypertens. 2003;42:1206-52. Available at: http://www.nhlbinih.gov/files/docs/ guidelines/jnc7full.pdf.

12. Okpechi I, Oluleye TS, Bekibele CO, Adedapo KS, Adebiyi AA, Ogah OS, et al. Unexpectedly high prevalence of target-organ damage in newly diagnosed Nigerians with hypertension: cardiovascular topic. Cardiovasc J Afr. 2007; 18(2):77-83. Available at: http://www.ncbi.nlm.nih.gov/pubmed/17497043.

13. Choi $Y$. The incidence and associated factors of hypertensive retinopathy among hypertensive patients attending Mulago Hospital. Makerere University Institutional Repository. 2005: Available at: http://makir.mak.ac.ug/handle/ 10570/1593. Accessed 17 Oct 2016.

14. Erden S, Bicakci E. Hypertensive retinopathy: incidence, risk factors, and comorbidities. Clin Exp Hypertens. 2012;34(6):397-401. Available at: http://www.ncbi.nlm.nih.gov/pubmed/22468968.

15. Wong TY, Klein R, Duncan BB, Nieto FJ, Klein BEK, Couper DJ, et al. Racial differences in the prevalence of hypertensive retinopathy. Hypertens. 2003; 41:1086-91. Available at: http://hyper.ahajournals.org/content/41/5/1086.full.

16. Ong $Y T$, Wong $T Y$, Klein $R$, Klein $B E$, Mitchell $P$, Sharrett $A R$, et al. Hypertensive retinopathy and risk of stroke. Hypertens. 2013;62(4):706-11. Available at: http://www.ncbi.nlm.nih.gov/pubmed/23940194.

17. Kim GH, Youn HJ, Kang S, Choi YS, Moon Jl. Relation between grade II hypertensive retinopathy and coronary artery disease in treated essential hypertensives. Clin Exp Hypertens. 2010;32(7):469-473. Available at: http:// www.tandfonline.com/doi/full/10.3109/10641963.2010.496515?src=recsys.

18. Addo J, Smeeth L, Leon DA. Hypertensive target organ damage in Ghanaians civil servants with hypertension. PLoS One. 2009;4(8):e6672. Available at: http://www.ncbi.nlm.nih.gov/pubmed/19701488.

19. Gallego PH, Maria E, Craig ME, Hing S, Donaghue KC. Role of blood pressure in development of early retinopathy in adolescents with type 1 diabetes: prospective cohort study. BMJ. 2008;337:a918. Available at: http://www.bmj. com/content/337/bmj.a918.

20. Chatterjee S, Chattopadhya S, Hope-Ross M, Lip PL. Hypertension and the eye: changing perspectives. J Hum Hypertens. 2002;16:667-75. Available at: http://www.ncbi.nlm.nih.gov/pubmed/12420190

21. Yip W, Sabanayagam C, Teo BW, Tay WT, Ikram MK, Tai ES, et al. Retinal microvascular abnormalities and risk of renal failure in Asian populations. PLoS One. 2015;10(2):e0118076. Available at : http://journals.plos.org/ plosone/article?id=10.1371/journal.pone.0118076.

22. Johnson RJ, Nakagawa T, Jalal D, Sánchez-Lozada LG, Kang D, Ritz E. Uric acid and chronic kidney disease: which is chasing which? Nephrol Dial Transplant. 2013;28(9):2221-8. Available at: http://www.ncbi.nlm.nih.gov/ pubmed/23543594.

23. Grunwald JE, Alexander J, Ying GS, Maguire MG, Daniel E, Whittock-Martin R, et al. Retinopathy and chronic kidney disease in the Chronic Renal Insufficiency Cohort (CRIC) Study. Arch Ophthalmol. 2012;130(9):1136-44. Availabble at: http://www.ncbinlm.nih.gov/pubmed/22965589.

24. Baltatzi M, Savopoulos $\mathrm{CH}$, Hatzitolios A. Role of angiotensin converting enzyme inhibitors and angiotensin receptor blockers in hypertension of chronic kidney disease and renoprotection. Study results. Hippokratia. 2011; 15 Suppl 1:27-32. Available at: http://www.ncbi.nlm.nih.gov/pmc/articles/ PMC3139675/.

\section{Submit your next manuscript to BioMed Central and we will help you at every step:}

- We accept pre-submission inquiries

- Our selector tool helps you to find the most relevant journal

- We provide round the clock customer support

- Convenient online submission

- Thorough peer review

- Inclusion in PubMed and all major indexing services

- Maximum visibility for your research

Submit your manuscript at www.biomedcentral.com/submit

) Biomed Central 